Haryoko \& Jaya, 2018

Volume 4 Issue 1, pp.143-154

Date of Publication: $2^{\text {nd }}$ May 2018

DOI-https://dx.doi.org/10.20319/mijst.2018.41.143154

This paper can be cited as: Haryoko, S., E Jaya, H. (2018). The Role of Multimedia Technology (LavirVirtual Laboratory) In Developing Life Skills in Vocational Schools. MATTER: International Journal of Science and Technology, 4(1), 143-154.

This work is licensed under the Creative Commons Attribution-Non-commercial 4.0 International License. To view a copy of this license, visit http://creativecommons.org/licenses/by-nc/4.0/ or send a letter to Creative Commons, PO Box 1866, Mountain View, CA 94042, USA.

\title{
THE ROLE OF MULTIMEDIA TECHNOLOGY (LAVIR- VIRTUAL LABORATORY) IN DEVELOPING LIFE SKILLS IN VOCATIONAL SCHOOLS
}

\author{
Sapto Haryoko \\ Department of Electronic Engineering, Makassar State University, Makassar, Indonesia \\ saptoharyoko27@gmail.com \\ Hendra Jaya \\ Department of Electronic Engineering, Makassar State University, Makassar, Indonesia \\ hendra070982@gmail.com
}

\begin{abstract}
The aim of research is to conduct a practicum, the school will need several factors which are a laboratory for each practical subject, equipment facilities and complete practicum material. Students hope to gain more knowledge and experience as study results, while teachers, on the other hand, expect that practical learning process can bring achievement in term of better cognitive, psychomotor, affective changes, and improvement of student life skill. It was found that the use of this Virtual Laboratory Model by SMK students can develop their life skills such as personal skills, thinking skills, social skills, and vocational skills. For Personal Skills, the mean score of test is 4.14 (good), Thinking Skills mean score is 4.06 (good), Social Skills mean score is 4.32 (very good), and for vocational skills, the score is 4.30 (very good). Furthermore, in this study, it was also found that data or information on the process of learning life skills (life
\end{abstract}


skills) consists of several aspects: (1) aspects of planning, include: curriculum, financial and facilities; (2) aspects of implementation, including: methods and techniques, media, competence tutor, materials or teaching materials, and time / schedule; (3) aspects of evaluation, including assessment of learning outcome. After producing a virtual laboratory model, this research carried out trial test on the developed product to several students of partner SMKs and other SMKs in Makassar

\section{Keywords}

Life skills, Vocational, Multimedia

\section{Introduction}

Recently, the development of education today has entered an era which marked by excessive technological innovation (Raju, 2015), so that the adjustment of education system is required to be in tune with the demands of the working world. Vocational High School (SMK) is designed to prepare students or students to be ready to enter the world of work and be able to develop a professional attitude in the field of vocational, and should also be able to provide competency or skill that can improve the quality of graduates to achieve their success. The success of the SMK can't be separated from its learning process and practical process. Several subjects practicum include not only the basic concepts and supporting theories, but also require the students to conduct experiments / trials in the laboratory in order to understand a particular concept or basic theories that have been studied so that they will have a broader understanding level. To carry out a practicum, the subject will require several factors, including laboratory space in accordance with the practice of subjects, facilities equipment, and a complete practice material. After conducting an observation in the field, the fact showed that there were many vocational schools have limited equipment and material practices. There are even several schools that still do not have a laboratory space. This makes the practicum process in their schools is not running optimally. Students hope to gain more knowledge and experience as study results, while teachers, on the other hand, expect that practical learning process can bring achievement in term of better cognitive, psychomotor, affective changes, and improvement of student life skill.

Virtual lab-based learning system developed on the assumption that the computing environment and the development of multimedia applications is an effective teaching tool that can improve students' learning ability (Janicki, 2001). Virtual lab-based learning system is a 
learning process in which students involve directly, follow the process, observe objects, analyze, and draw conclusions on an object in which situation and process of the material being studied is done in a virtual laboratory. Therefore, practical activities may not necessary be done in a laboratory room with complete and expensive equipment and materials. Moreover, it will not limit the student's time for creativity. Therefore, it is necessary to develop a virtual laboratory that can overcome the shortfall in a conventional lab.

Limitations of practicum equipment and materials can be overcome with the use of multimedia learning (Hofstetter, 2001). Learning with virtual media (computer animation) and non-virtual media (conventional) are equally good to be used to improve student learning outcomes both in cognitive and affective aspects (Utaminingsih, 2009).

One form of multimedia learning is a virtual laboratory (Zysman, 1997). Virtual laboratory is defined as an interactive environment that be used to create and perform simulation (Phyoe, 2016) experiments which were designed with three-dimensional effect that will display the equipment looks like a real lab equipment. Practicum through virtual lab is inseparable from the efforts to improve the competence of the students that emphasize on the cognitive abilities (knowledge), psychomotor (skills), and especially the affective (attitude / character) that will be formed through values, attitudes, personality, honesty, perseverance, mental emotional and spiritual, able to cooperate or collaborate. The students are also expected to appreciate other people. The students will learn with fun and excitement. Building character has a very important role in determining a person that be useful for them in doing their job, and as a preparation for entering the college level.

Those problems can be overcome with several advantages of virtual laboratories such as (Rebecca K, 2003): 1) this activity use a computer to replace a laboratory that bring many benefits in learning, 2) virtual laboratory is a new phenomenon, 3) digital lab can minimize budget, 3) with a virtual lab, students may obtain entertainment facilities for learning, and 4) only virtual lab that is interactive and has self-regulation in learning. Therefore, the virtues of this research are the increasing life skills of vocational students through the use of virtual labs before entering the stage of entrepreneurship and industry.

Life skills as a continuum of knowledge and skills is needed by an individual to function independently in life (Anwar, 2006). Another opinion says that life skills are skills required daily by a person to be successful in running life. Life skills is defined "as abilities for 
adaptive and positive behavior that enable individuals to deal effectively with the demands and challenges of everyday life" (Departemen Pendidikan Nasional, 2002). Life skills also mean as the ability to adapt and to have positive behavior that enable a person to face all the demands and challenges in his life. In addition, life skill is also viewed as a skill that one has to be willing and courageous to face the problems of life and living naturally without feeling pressured, then proactively and creatively search for and find a solution so that ultimately he may be able to overcome the problems.

From some opinions above, it can be concluded that the life skills is the ability of learners to adjust attitudes and behaviors that allow him to overcome various problems of everyday life. Life skills are often associated with the acquisition of various competencies in preparation of students for life in the community. Competence actually has a very broad sense as it covers all skills and habits that are needed by someone in his life, both as personal and working life, as well as community members. Competence has a similar meaning to the skills / life skills, i. e abilities, skills to express, preserve, maintain, and develop themself (Sukmadinata, 2007).

The concept of life skills as mandated in UUSPN No. 20 in 2003 and PP 19 in 2005, and which have been developed previously can be illustrated in Figure 1 below:

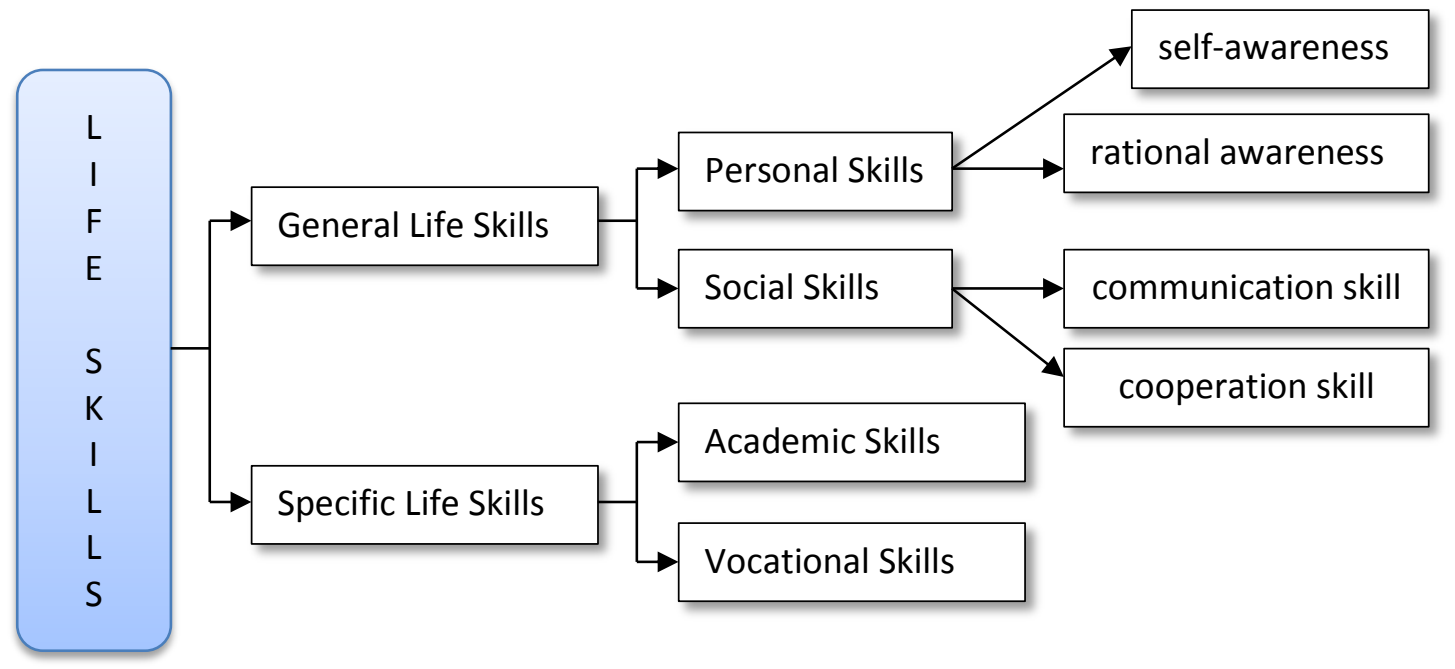

Figure 1: The concept of life skills (Depdiknas, 2007)

From Figure 1, it appears that life skills can be divided into two main types, namely: (1) generic life skills (GLS), and (2) specific life skills (SLS). Each type of skill that can be divided 
into several sub-skills. Generic life skills consist of personal skills and social skills. Personal skills include proficiency in understanding oneself (self awareness skills) and thinking skills. Proficiency to know ourselves basically is an appreciation of ourselves as creatures of God Almighty, as a member of society and citizens, as well as to realize and appreciate the strength and limitation that can be used as an asset in improving ourselves as individuals that are beneficial to the environment. Proficiency thinking skills include the skills to identify and find the information, process, and make decisions, and solve problems creatively. Finally, the social skills include communication skills and proficiency in collaboration (collaboration skills).

Life skills are skills specific to face the job or certain circumstances. This skill consists of academic skills or intellectual skills, and vocational skills. Academic skills associated with occupations that require more thought or intellectual work. Vocational skills associated with occupations that require more motor skills. Vocational skills are divided into basic vocational skills and specific vocational skills (occupational skill).

\section{Research Methodology}

This research is a development research. The research and development model in the field of education and learning is defines as "a process used to develop and validate educational products" (Borg \& Gall, 2003). Development of software in the form of a virtual laboratory model was implemented with engineering approach where the stages are: analysis, design, implementation, and evaluation. Having produced a model of the Virtual Laboratory, then the second stage of this research was continued by conducting tests on developed products for students of several partner vocational schools and other vocational schools in Makassar city. The trial subjects in this study were taken by using purposive sampling. The trial subjects were students majoring in electronics and computer engineering network class XI at SMK 1 South Sulawesi Province. Data used in this study is both qualitative and quantitative data. Qualitative data obtained from the instrument needs analysis, while quantitative data obtained from the analysis sheet and students respond sheet. The result obtained in this study was the increase in life skills of vocational students after using the virtual laboratory. 


\section{Results and Discussion}

\section{Life Skills in designing and implementing LAVIR learning in schools}

One of goals to develop LAVIR models in this study is to develop life skills of vocational students in productive subjects. This model is adapted to the learning conditions of practical learning such as by looking at the characteristics of learners, LAVIR material and models that are expected to develop life skills of learners (Fig. 1)

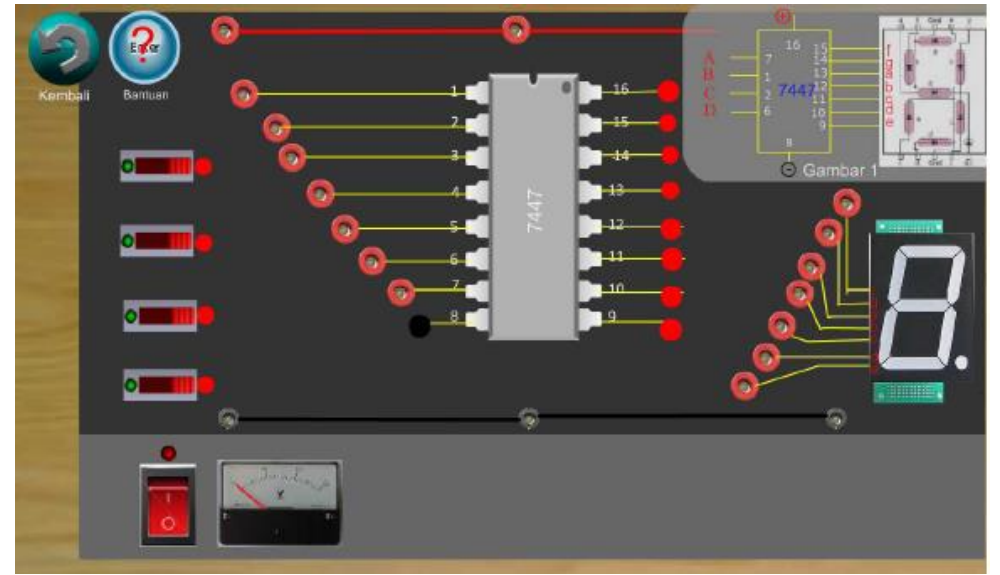

Figure 2 : Multimedia Technology LAVIR (Virtual Laboratory)

This developed model is a comprehensive model which was taken from several models, including models of research and development in the field of education and learning as "a process used to develop and validate educational products" (Borg \& Gall, 2003). The development activities (Babayemi, 2017) started from the definition phase (which is the starting point of activities), heading out towards the design phase, demonstrations, development, and presentation which was carried out in spiral process and involves prospective users, experts from developed field (subject matter experts), team members, instructors, and learners. At each phase of development, the developers will always pay attention to the elements of the learning outcomes, activities, learners, assessment and evaluation. Developer in every phase repeatedly face with the important elements in learning design such as learning goals, learning activities, student, assessment and evaluation. The overall model was developed into a model which is LAVIR models that have been applied and tested in vocational through one to one test, small group test, and field test.

This study was conducted to determine the outcome of LAVIR model design (Virtual Laboratory) that may develop life skills of vocational students. Therefore, several instruments 
were designed for assessing aspects which can develop life skills. The term "life is not merely meant that one individual has certain abilities (vocational job), but he must also have the supporting ability to function such as basic reading, writing, counting, formulate, and solve problems, manage resources, work in teams, continue to learn on the spot work, and can use the technology (Satori, 2003).

Other sources interpret life skills as extensive knowledge and interaction skills are thought to be essential for adult to be able to live independently (Brolin, 1989). Other argument stated that life skills is a personal guide for the human body that helps children learn how to maintain a healthy body, grow as individuals, to work well, make logical decisions, keep their own when necessary and to reach the goal of life (Kent Davis, 2008). Life skills are also interpreted as the skills of a person to dare to face the problems of life and live naturally without feeling pressured, then proactively and creatively search for and find a solution so that he ultimately will be able to cope with the problems. Ability is the realization of the life skills that are cognitive (knowing how to do). The ability is the realization of the life skills that are more affective (will or impulse to behave), and skill is the realization of the life skills that are psychomotor (action taken on the basis of knowledge and willingness).

Furthermore, to obtain accurate data or information on the variables of the process of learning life skills, researchers used a questionnaire research instruments. Questionnaire were made in which there are several questions relating to the variable and must be filled directly by sample with an alternative option a, b, c, d, and e. Several items were also made in the form of questions related to variable of life skills in learning process. The questionnaire was given a weighting value to each of the options as well by using the same Liker scale as the weighted value of the learning environment variable. Formulation on each question based on the subvariables, including: (1) aspects of planning, include: curriculum, financial and facilities; (2) aspects of implementation, including: methods and techniques, media, competence tutor, materials or teaching materials, and time / schedule; (3) aspects of evaluation, including assessment of learning outcomes.

Regarding the assessment of life skills of vocational students, it can be seen in Table 1 which will start from the planning, implementation, and evaluation. Based on the implementation of the practical learning process in vocational schools using LAVIR and indicators of life skills assessment results as presented in Table 1, it is known that planning is becoming an important 
factor for developing life skills of students as it will relate to the problems of financing and facilities. LAVIR financing sourced from DP2M Higher Education through the National Strategic Grant funds, thus the cost issue is not an obstacle in the development of life skills of students. The second indicator of the planning is facilities. Appropriateness and completeness of the LAVIR practicum materials based observer and student assessment show result which is in conformity assessment states and already complete.

The results of component assessment after implementation of LAVIR showed that the indicators of method and technique with its sub-indicator about the fitness between method and technique LAVIR is score 4.00 which is in Very Good Category. The ability of tutor in using the method/technique is 3.81 which is in Good category. The suitability with the objective is scored 4.37(very good category). The assessment of the suitability with learning material obtains score of 4.30 (very good category).

Assessment of the indicators with sub-indicators Media Conformity with instructional materials obtained score 4.19 with category Good; Conformity assessment with learning goals 4.37 score obtained (Very Good category); assessment scores of the media attractiveness media obtained score 4.15 with Good category. Assessment score of media completeness is 4.33 with very Good category.

Tutor Competence Assessment consists of sub-indicators tutor ability conformity with the needs of the learners show the results of the assessment with a mean score of 4.22 with the category of Very Good. Ability tutors in selecting teaching materials indicated with a mean score of 4.19 with good category. Furthermore, ability tutor in implementing the learning is considered very good with a mean score of 4.44. Ability tutor in using methods and techniques Compliance with the curriculum is considered good with a mean score of 4.19. The latter is the attractiveness of the teaching materials and easy to understand rated Good with a mean score of 4.11. As for the Evaluation component of Learning Outcomes with indicator objectivity of learning assessment is 4.30 that is considered very good. Finally, assessment of the Evaluation Tool is considered good with a mean score of 3.96 . 
Table 1: Life skills assessment in the planning and implementation of LAVIR Learning (Virtual Laboratory) in Schools

\begin{tabular}{|c|c|c|c|c|}
\hline COMPONENT & INDICATOR & SUB INDICATOR & MEAN & COMENT \\
\hline \multirow{4}{*}{ PLANNING } & \multirow[t]{2}{*}{ Financial } & Funded source & & DP2M Dikti \\
\hline & & Budget Allocation & & Grant \\
\hline & \multirow{2}{*}{ Facilities } & Suitability & & Matched \\
\hline & & Completeness & & Complete \\
\hline \multirow{13}{*}{ Implementation } & \multirow{4}{*}{ Methods and Technique } & $\begin{array}{l}\text { The suitability with learning } \\
\text { goals }\end{array}$ & 4.00 & Good \\
\hline & & $\begin{array}{l}\text { The ability of tutor in using } \\
\text { method/technique }\end{array}$ & 3.81 & Good \\
\hline & & Fulfill the objectives & 4.37 & Very Good \\
\hline & & $\begin{array}{l}\text { The suitability with learning } \\
\text { material }\end{array}$ & 4.30 & Very Good \\
\hline & \multirow{4}{*}{ Media } & $\begin{array}{l}\text { The suitability with learning } \\
\text { material }\end{array}$ & 4.19 & Good \\
\hline & & $\begin{array}{l}\text { The suitability with learning } \\
\text { goals }\end{array}$ & 4.37 & Very Good \\
\hline & & The attractiveness of media & 4.15 & Good \\
\hline & & The completeness of media & 4.33 & Very Good \\
\hline & \multirow{5}{*}{$\begin{array}{c}\text { Tutor } \\
\text { Competency }\end{array}$} & $\begin{array}{l}\text { The suitability of tutor ability } \\
\text { with the learning community }\end{array}$ & 4.22 & Very Good \\
\hline & & $\begin{array}{l}\text { The ability of tutor in selecting } \\
\text { learning material }\end{array}$ & 4.19 & Good \\
\hline & & $\begin{array}{l}\text { The ability of tutor in } \\
\text { implementing learning process }\end{array}$ & 4.44 & Very Good \\
\hline & & $\begin{array}{l}\text { The ability of tutor in using } \\
\text { method and technique the } \\
\text { suitability with curriculum }\end{array}$ & 4.19 & Good \\
\hline & & $\begin{array}{l}\text { The attractiveness learning } \\
\text { material and easy to } \\
\text { understanding }\end{array}$ & 4.11 & Good \\
\hline \multirow[t]{2}{*}{ Evaluation } & \multirow{2}{*}{$\begin{array}{l}\text { The assessment of } \\
\text { learning material }\end{array}$} & Objectivity & 4.30 & Very Good \\
\hline & & Evaluation tools & 3.96 & Good \\
\hline
\end{tabular}

\section{Conclusion}

The Use of LAVIR model (Virtual Laboratory) by SMK students can develop their life skill which are personal skills, Thinking Skills, social skills, and vocational skills. Personal Skills obtained a mean score 4.14 (good), Thinking Skills got a score 4.06 (good), Social Skills score was 4.32 (very good), and finally Vocational Skills gained mean score 4.30 (very good). Furthermore, in this study, it was also found that data or information on the process of learning 
life skills (life skills) consists of several aspects: (1) aspects of planning, include: curriculum, financial and facilities; (2) aspects of implementation, including: methods and techniques, media, competence tutor, materials or teaching materials, and time / schedule; (3) aspects of evaluation, including assessment of learning outcomes.

\section{Recomendations}

In a subsequent study is a follow up from previous studies that specifically focused on the development of research and field trials, test experiments on a model developed to vocational students. It is necessary for implemented to vocational students to determine the impact of the use of models of lab-based virtual involving public and private schools, schools that lack equipment and adequate lab, school character and quite nice. If successful, the model developed can be applied to vocational nationally so that vocational students who will be entering the college level and who will enter the industry already has the skills and mental abilities of good character. Thus the benefits are huge brawl between students can be suppressed, the brawl at the time of going to college can be suppressed because by the time the new student has been facilitated with character education. able to address issues such as limitations on conventional lab time and place to implement lab, lab equipment is still minimal due to the high cost of equipment and maintenance costs, and eliminate the assumption that the practicum is difficult and boring subjects. Increasing the effectiveness of the learning process Practicum after the implementation of media-based virtual lab.

\section{Acknowledgement}

Further thanks to the Director General of Higher Education (DRPM Dirjen Dikti) that has provided research grants. Further gratitude to Prof. Adhi Susanto, professor of Electronics Gadjah Mada university engineering faculty for their guidance and input in the completion of this article 


\section{References}

Anwar. 2006. Pendidikan Kecakapan Hidup (Life Skill Education).Bandung: Alfabeta.

Babayemi. (2017). Communicating Research Findings In Basic Science And Technology For Technological Development. MATTER: International Journal of Science and Technology ISSN 2454-5880. regular Issue Volume 3 Issue 1, pp. 01 - 15 Date of Publication: 15th July, 2017. DOI- https://doi.org/10.20319/Mijst.2017.31.0115

Borg, W. R \& Gall, M.D. (2003). Educational Research: An Introduction. New York: Longman. Inc.

Brolin, D.E. (1989). Life Centered Career Education: A Competency Based Approach. Reston, VA: The Council for Exceptional Children.

Depdiknas (2007). Konsep Pengembangan Model Integrasi Kurikulum Pendidikan Kecakapan Hidup (Pendidikan Menengah). Jakarta: Badan Penelitian dan Pengembangan Pusat kurikulum.

Hofstetter F.T., (2001). Multimedia literacy (3rd Ed.). New York: McGraw- Hill/Irwin.

International Center for Alcohol Policies (ICAP). (2000). Life skills education in South Africa and Botswana. Washington DC: Author

Janicki, T., \& Liegle, J. O. 2001. Development and evaluation of a framework forcreating webbased learning modules: A pedagogical and systems approach. Journal of Asynchronous Learning Networks, 5(1). Retrieved June, 2015, from http://www.sloan-c.org/publications/ jaln/v5n1/pdf/v5n1_janicki.pdf

Kent Davis . 2008. The Million Dollar Machine - Character Education - Life Skills Enrichment Program - Grades K-3. Amazon.com

Michael Duarte, \& Brian P. Butz (2001). The virtual laboratory for the disabled. Makalah disajikan pada 31th ASEE/IEEE Frontiers in Education Conference, 13, 1-4. https://doi.org/10.1109/FIE.2001.963989

S.M. Phyoe. (2016). An Air Traffic Forecasting Study And Simulation. MATTER: International Journal of Science and Technology ISSN 2454-5880. S.M. Phyoe. et al. Regular Issue Volume 2 Issue 3, pp. 55-69 Date of Publication: 15th November, 2016 DOIhttps://doi.org/10.20319/Mijst.2016.23.5569

Raju, Valliappan. (2015). Role Of Information Technology In Education Sector: Scrutinizing Its Merits And Developments. MATTER: International Journal of Science and Technology. 
ISSN 2454-5880. Matter Vol. 2 Issue 1, pp. 12-20. DOIhttp://dx.doi.org/10.20319/mijst.2016.21.1220

Scheckler, Rebecca K. 2003. Virtual labs: a substitute for traditional labs?. Int. J. Dev. Biol. 47: 231-236.

Satori, Djam'an dan Udin, S. Saud. (2003). Implementasi Program "Life Skills" dan "Broad Based Education" Sebagai Strategi Peningkatan Mutu Pendidikan Dasar dan Menengah. Bandung: Jurnal Adpen UPI.

Sukmadinata, N.S.(2007) “Kurikulum dan Pembelajaran” dalam Ali, M. dkk. Ilmu dan Aplikasi Pendidikan (Handbook). Bandung: Pedagogiana Press

Tim Broad Based Education, Departemen Pendidikan Nasional, 2002. Pendidikan berorientasi kecakapan hiudp (life skill) melalui pendekatan pendidikan berbasis luas broad based education (BBE).

Utaminingsih. Retno (2009). Perbedaan peningkatan hasil belajar siswa pada pemanfaatan media virtual dan media non virtual dalam pembelajaran sains di SMP negeri 2 Wanadadi Banjarnegara tahun ajaran 2008/2009. Magister Thesis, Unpublished, Education Study Program, School of Graduate Studies Universitas Negeri Yogyakarta, Yogyakarta.

Wagner, D. L. (1994). Using digitized video for motion analysis. The Physics teacher, 32, 240243. https://doi.org/10.1119/1.2343982

Zysman., E. (1997). Multimedia virtual lab in electronics. Proceedings, international conference on Microelectronics System Education, Switzerland. 4, 151-152. https://doi.org/10.1109/MSE.1997.612590 